\title{
A Novel Hydro Powered Online Power Converter for Marine Lighting Applications
}

\author{
Sinu KJ $\mathbf{J}^{1}$, G. Ranganathan ${ }^{2}$ \\ ${ }^{1}$ Department of EEEM, AMET University, Chennai \\ ${ }^{2}$ Department of Electrical and Electronics Engineering, PSG Institute of Advanced Studies, Coimbatore
}

\begin{tabular}{l} 
Article Info \\
Article history: \\
Received Aug 9, 2017 \\
Revised Nov 20, 2017 \\
Accepted Dec 11, 2017 \\
\hline Keywords: \\
Power Factor Correction (PFC) \\
Single Ended Primary Inductor \\
Converter (SEPIC) \\
Total Harmonic Distortion \\
(THD)
\end{tabular}

\section{Article Info}

Article history:

Received Aug 9, 2017

Revised Nov 20, 2017

Accepted Dec 11, 2017

(THD)

\begin{abstract}
This paper presents a new hydro energy based dc-dc PFC sepic based buck converter for marine lighting applications. The major advantage of the proposed power converter is high power factor and low THD with higher efficiency. SEPIC converter produces continuous smooth ripple free current because of two inductors in series in line in its circuit. Sepic converter produces lower switching losses because of lower voltage stress on power switch employed compared to other buck-boost converter topologies. Tidal wave energy is converted into mechanical energy with the help of a hydro turbine which drives a permanent magnet synchronous generator to produce three phase ac output voltage. It produces a low ac voltage which is converted into DC using passive diode rectifier and fed to sepic converter for voltage regulation as well as to improve quality of power supply such as high power factor, low THD. The proposed sepic based power converter for marine lighting application is simulated in MATLAB/Simulink environment for verifying the performance of proposed scheme.
\end{abstract}

Copyright $\left(C_{0} 2018\right.$ Institute of Advanced Engineering and Science. All rights reserved.

\section{Corresponding Author:}

Sinu KJ,

Research Scholar, Department of EEEM,

AMET University, Chennai.

\section{INTRODUCTION}

Single source renewable energy based buck boost converters cannot supply a load or a drive if produced output from source is very less. Hence if more than one source is used for a converter operation of inverter is possible with either of the source. Power factor corrected power electronic converter has integrated one or more sources like solar with maximum power point tracking based boost converter and PMSG hydro turbine based three phase sepic based power-factor-correction buck-boost rectifier can improve power factor and achieve less total harmonic distortion (THD) power converter.

\section{Problem Description}

Power supplies designed for lighting applications suffers from poor power factor and higher order harmonics in the line. Hence it degrades power system quality.

\section{Background}

[1] Proposed a control system for permanent magnet synchronous generator based wind energy system. [2] Presented a PFC rectifier for PMSG based wind system. Multiport dc-dc converter with three inputs PV, battery, super capacitor for reliable operation [3-5]. [6] Discussed modeling of photovoltaic system with converter topology for grid fed operations. A reactive power controller for power quality enhancement of wind energy conversion systems. Bidirectional multiport dc-dc converters are required for double side energy transfer applications such as energy storage systems including battery, super conducting energy storage systems. The paper [7] portrayed grid connected renewable energy conversion systems were 
designed to analyze an impact of parameter variations on the steady state behaviour. A Study on 3-phase Interleaved DC-DC Boost Converter Structure and Operation for Input Current Stress Reduction [8]. Hardware Implementation of Solar Based Boost to SEPIC Converter Fed Nine Level Inverter System [9]. Transformer Less Voltage Quadrupler Based DC-DC Converter with Coupled Inductor and PI Filter for Increased Voltage Gain and Efficiency [10]. Solar Photovoltaic Array FED Water Pump Riven by Brushless DC Motor using KY Converter [11].

\section{PROPOSED PFC SEPIC CONVERTER}

Figure 2 Shows Block Diagram of proposed PFC SEPIC converter for marine lighting applications. Single ended primary inductor converter (SEPIC) is sort of DC-DC converter permitting the electrical potential (voltage) at its yield to be more noteworthy than, not exactly, or square with to that at its info; the yield of the SEPIC is controlled by the obligation cycle of the control transistor. The standard Sepic Rectifier is appeared in figure 1. This topology is like the bridgeless lift power factor correction rectifier. In spite of the specified preferred standpoint, in contrary with the ordinary SEPIC converter, this converter has three more inductors and capacitors (passive elements) which add to the size and cost of the converter. Another significant issue with this converter is that it pairs the yield voltage which extensively expands the span of yield channel. To overcome the above mentioned problems associated with SEPIC converter, another power factor corrected SEPIC is presented in this paper. The proposed converter does not require any additional (inactive or dynamic) components in comparison with established SEPIC PFC.

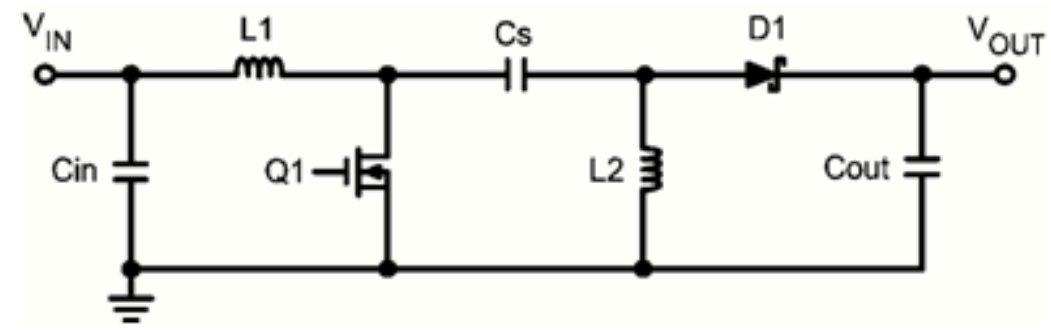

Figure 1. Circuit Diagram of PFC SEPIC Converter

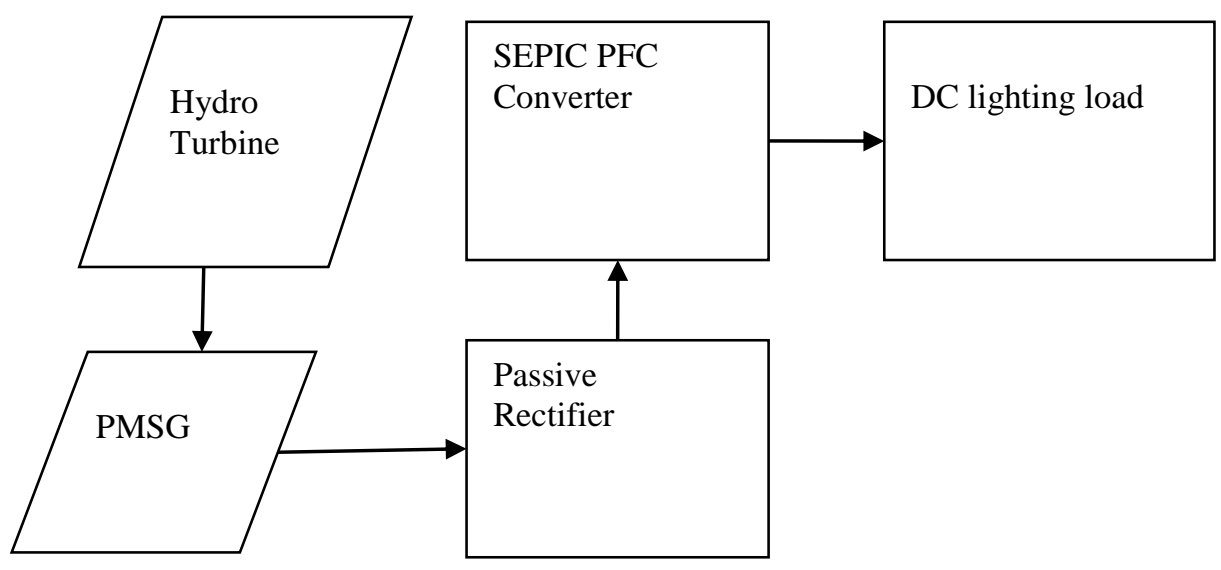

Figure 2. Block Diagram of Proposed PFC SEPIC Converter for Marine Lighting Applications

\section{SIMULATION RESULTS AND DISCUSSION}

The proposed solar and PMSG wind based multiport port dc-dc converter is implemented in MATLAB/Simulink platform and results are presented here. Figure 3 Shows simulation implemented circuit of proposed PFC sepicconverter for marine lighting applications. Figure 4 Shows Voltage response of proposed PFC sepic converter. Figure 5 to 7 shows performance of proposed PFC sepic converter, PMSG hydro turbine output of single phase, power factor correction response and total harmonic distortion values. Table1.Shows simulation parameters of proposed circuit used in Simulink platform. 


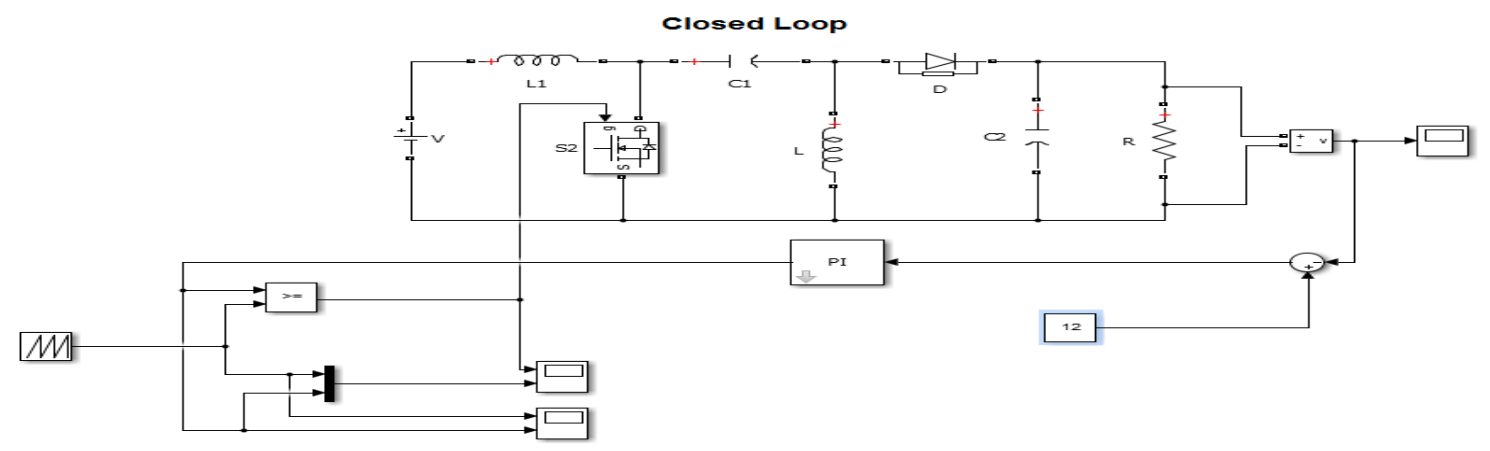

Figure 3. Simulation Implementation of Proposed Multiport DC-DC Converter

Table 1. Simulation parameters

\begin{tabular}{cc}
\hline & $10 \mathrm{k} \mathrm{ohms}$ \\
Resistance R1 & $1 \mathrm{ou} \mathrm{H}$ \\
Inductance L1 & $220 \mathrm{uF}$ \\
Capacitance $\left(C_{1}, C_{2} C_{3}\right)$ & $1000 \mathrm{uF}$ \\
Output Capacitor $\left(C_{01}, C_{02}\right)$ & $1 \mathrm{ohms}$ \\
\hline Load resistor
\end{tabular}

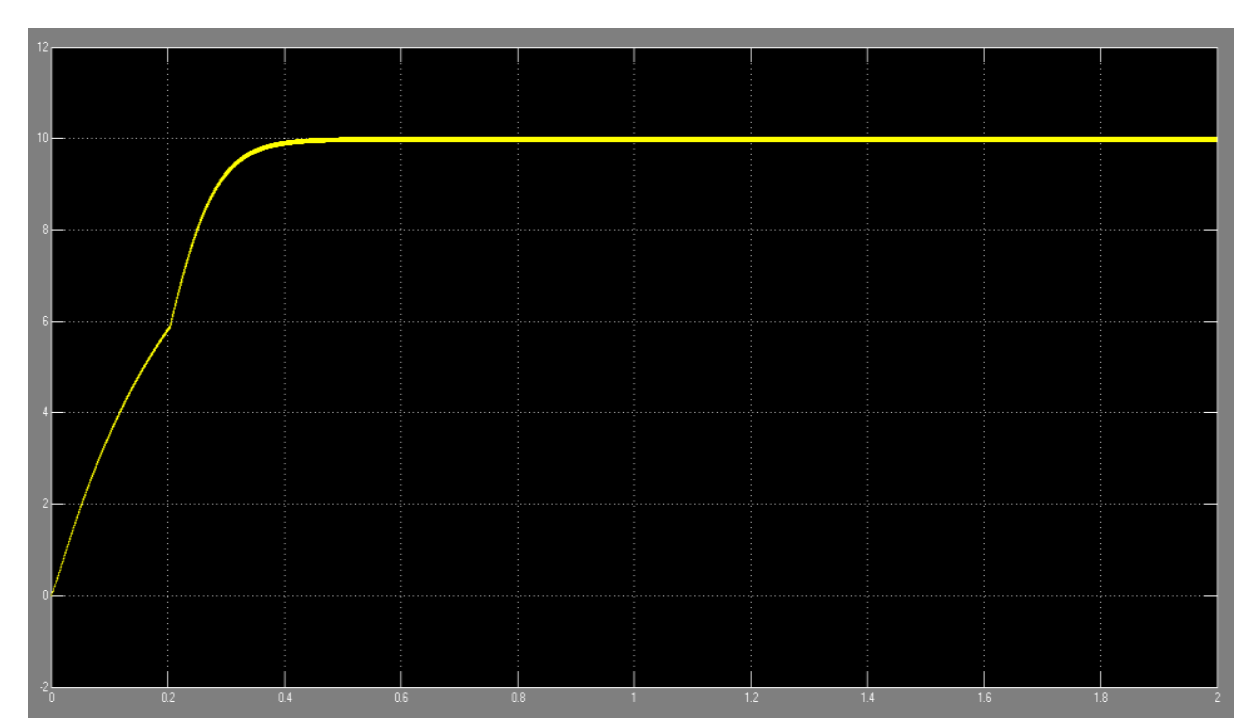

Figure 4. Voltage Response of Proposed PFC Sepic Converter

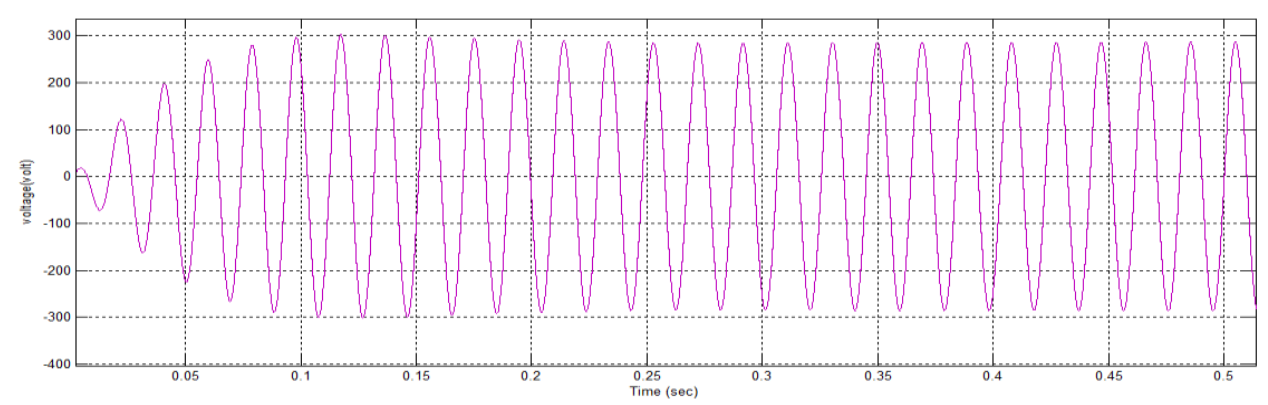

Figure 5. PMSG Hydro Turbine Output of One Phase 


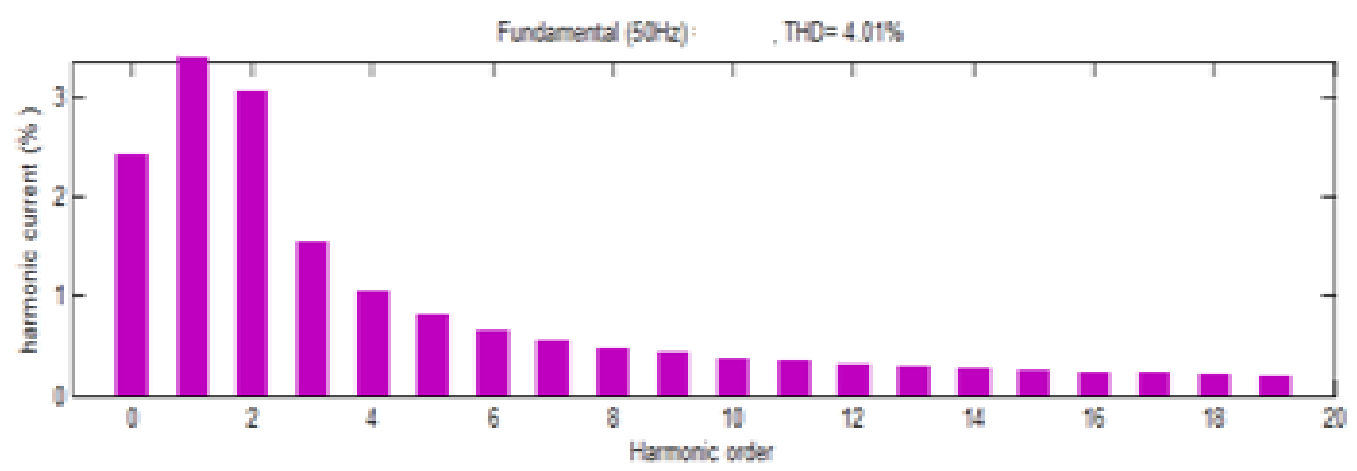

Figure 6. THD Performance of PMSG

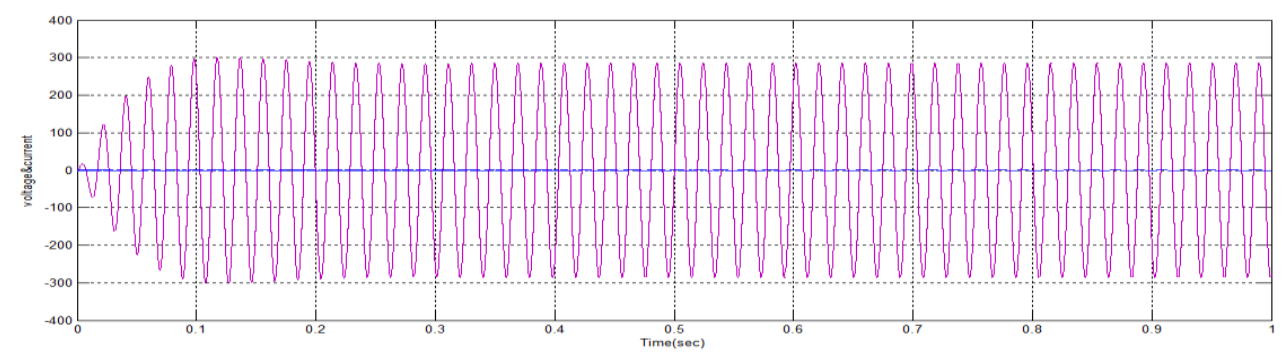

Figure 7. PFC using SEPIC Converter

\section{CONCLUSION}

This paper presented a new hydro energy based dc-dc PFC sepic based buck converter for marine lighting applications. The major advantage of the proposed power converter is high power factor and low THD with higher efficiency. SEPIC converter produces continuous smooth ripple free current because of two inductors in series in line in its circuit. Sepic converter produces lower switching losses because of lower voltage stress on power switch employed compared to other buck-boost converter topologies. Tidal wave energy is converted into mechanical energy with the help of a hydro turbine which drives a permanent magnet synchronous generator to produce three phase ac output voltage. It produces a low ac voltage which is converted into DC using passive diode rectifier and fed to sepic converter for voltage regulation as well as to improve quality of power supply such as high power factor, low THD. The sepic based power converter for marine lighting application is simulated in MATLAB/Simulink platform and the results verify the performance of the proposed converter.

\section{REFERENCES}

[1] Y. H. Liao and J. Y. Jhu, "Analysis and implementation of a bridgeless sepic AC/DC converter with power factor correction and extended gain", 2017 IEEE Applied Power Electronics Conference and Exposition (APEC), Tampa, FL, USA, 2017, pp. 416-423.

[2] Y. P. Siwakoti, M. Soltani, F. Blaabjerg and A. Mostaan, "A novel quasi-SEPIC high-voltage boost DC-DC converter", 2017 IEEE Applied Power Electronics Conference and Exposition (APEC), Tampa, FL, USA, 2017, pp. 2213-2216.

[3] Y. Yang, F. Liu and X. Chen, "A maximum power point tracking control scheme for magnetically coupled resonant wireless power transfer system by cascading SEPIC converter at the receiving side", 2017 IEEE Applied Power Electronics Conference and Exposition (APEC), Tampa, FL, USA, 2017, pp. 3702-3707.

[4] Z. W. Xu, Z. L. Zhang, K. Xu, Z. Dong and X. Ren, "2-MHz GaN PWM isolated SEPIC converters", 2017 IEEE Applied Power Electronics Conference and Exposition (APEC), Tampa, FL, USA, 2017, pp. 149-156.

[5] K. L. Bashar, S. Islam, M. A. Choudhury, A. H. Abedin and M. N. Uddin, "A modular one-switch three-phase Single Ended Primary Inductor (SEPIC) rectifier", 2017 IEEE International Conference on Industrial Technology (ICIT), Toronto, ON, 2017, pp. 24-29.

[6] Umadevi, K., Nalandha, P., \& Kesavan, C. C. Modelling of Photovoltaic System with Converter Topology for Grid fed Operations. 
[7] Abraham, A., \& Subramanian, D. P. (2014). Impact of parameter variations on the steady state behaviour of grid connected renewable energy conversion systems. Indian Journal of Science and Technology, 7(S6), 48-55.

[8] Harimon, M. A., Ponniran, A., Kasiran, A. N., \& Hamzah, H. H. (2017). A Study on 3-phase Interleaved DC-DC Boost Converter Structure and Operation for Input Current Stress Reduction. International Journal of Power Electronics and Drive Systems (IJPEDS), 8(4).

[9] Jasmine, D., \& Gopinath, M. (2016). Hardware Implementation of Solar Based Boost to SEPIC Converter Fed Nine Level Inverter System. International Journal of Power Electronics and Drive Systems, 7(4).

[10] Sujitha, C., Ravi, S., Diarra, B., \& Chuma, J. (2016). Transformer Less Voltage Quadrupler Based DC-DC Converter with Coupled Inductor and PI Filter for Increased Voltage Gain and Efficiency. International Journal of Power Electronics and Drive Systems, 7(4).

[11] Dinesh, B., Jaivinayagam, M., Udayakumar, M., \& Syedismail, S. Solar Photovoltaic Array FED Water Pump Riven by Brushless DC Motor using KY Converter. 